Folia Cardiologica 2019 tom $14, \mathrm{nr} 1$, strony $52-59$ DOI: $10.5603 /$ FC.a2018.0060 Copyright (C) 2019 Via Medica ISSN 2353-7752

\title{
Nowe markery biologiczne w kardiologii - czy to właściwy trop?
}

\section{New biological markers in cardiology - are we on the right track?}

\author{
Agata Tymińska, Krzysztof J. Filipiak \\ I Katedra i Klinika Kardiologii Warszawskiego Uniwersytetu Medycznego
}

\section{Streszczenie}

Istnieje wiele markerów oceny ryzyka chorób sercowo-naczyniowych (CVD). Wciąż poszukuje się nowych czułych i specyficznych biomarkerów, które mogłyby pomóc w stratyfikacji ryzyka zarówno wśród populacji zdrowej, jak i obciążonej CVD. Galektyna 3 oraz białko ST-2 wydają się niezwykle obiecującymi wskaźnikami, niemniej potrzebne są dalsze badania nad tymi cząsteczkami, aby poznać ich pełną wartość diagnostyczno-prognostyczną. W artykule zaprezentowano badania i publikacje przedstawiające możliwość wszechstronnego wykorzystania obu biomarkerów, zwłaszcza w chorobie wieńcowej. Galektyna-3 oraz białko ST-2, dzięki związkowi z procesami włóknienia, mogą się okazać kluczowymi markerami u pacjentów z chorobą wieńcową oraz po zawale serca.

Słowa kluczowe: białko ST-2, choroby układu sercowo-naczyniowego, choroba wieńcowa, galektyna 3, remodeling, zawał serca

Folia Cardiologica 2019; 14, 1: 52-59

\section{Wstęp}

Choroby sercowo-naczyniowe (CVD, cardiovascular diseases) należą do grupy chorób przewlekłych, zwykle rozwijają się przez całe życie. Są one najczęstszą przyczyną zgonów w Polsce (46\%), a jednocześnie cechują się wzrastającą chorobowością [1]. Dlatego też istotne jest posiadanie wskaźników usprawniających proces diagnostyczny CVD na różnych etapach choroby, a także prognozowanie ryzyka. Do najczęstszych CVD należy choroba wieńcowa. Wśród sprawdzonych wskaźników w ocenie początkowych stadiów miażdżycy wymienia się: grubość kompleksu błony środkowej i wewnętrznej tętnicy szyjnej wspólnej (IMT, intima-media thickness), pomiar sztywności naczyń i prędkości fali tętna (PMV, pulse wave velocity), wskaźnik kostka-ramię (ABI, ankle-brachial index), oznaczanie stężenia poszczególnych frakcji cholesterolu w surowicy. Ocena dynamiki stężenia troponin jest natomiast kluczowym elementem w diagnostyce martwicy mięśnia sercowego [2, 3]. Ostatnio można zaobserwować wzmożone zainteresowanie nowymi biochemicznymi markerami. Jednak aby je włączyć do nowych algorytmów, są potrzebne spójne dowody płynące z prospektywnych badań.

W niniejszym opracowaniu przedstawiono podsumowanie aktualnej wiedzy dotyczącej charakterystyki oraz potencjalnego wykorzystania galektyny 3 (Gal-3) i białka ST-2 (suppression of tumorigenicity 2) w kardiologii, zwłaszcza w chorobie wieńcowej.

\section{Charakterystyka biologiczna Gal-3} i białka ST-2

Galektyna 3 jest przedstawicielem galektyn należących do rodziny białek wiążących węglowodany (lektyn) $[4,5]$. Wykazuje budowę domenową - można wyróżnić w niej krótką domenę N-końcową, kolagenopodobną oraz nietypową 


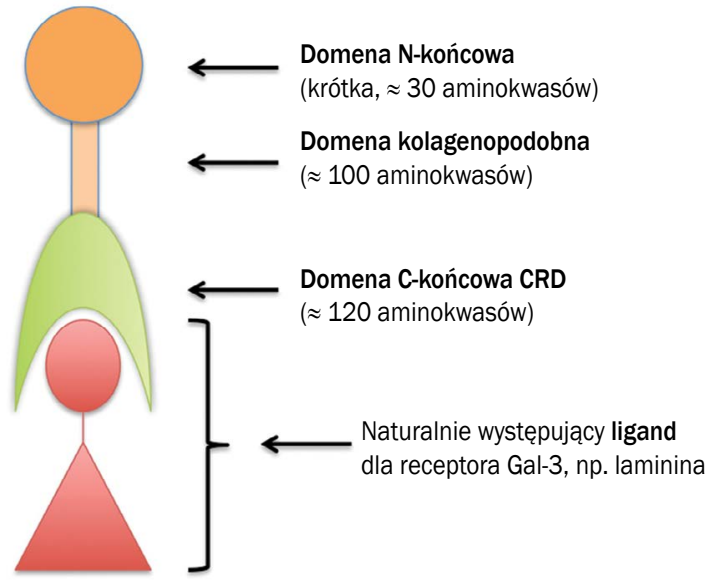

Rycina 1. Struktura galektyny 3 (Gal-3) (na podstawie [6]); CRD (carbohydrate recognition domain) - sekwencja rozpoznająca węglowodany

domenę C-terminalną, w której obrębie występuje sekwencja rozpoznająca węglowodany (CRD, carbohydrate recognition domain), dzięki której Gal-3 oddziałuje ze znaczną liczbą ligandów - między innymi receptorami znajdującymi się na powierzchni komórek, jak również z białkami przestrzeni zewnątrzkomórkowej, modulując adhezję międzykomórkową [4, 6] (ryc. 1). Znajduje się głównie w cytoplazmie, natomiast do jej ekspresji dochodzi w wielu typach komórek, na przykład w makrofagach, neutrofilach, fibroblastach, komórkach nowotworowych, dzięki czemu jest zaangażowana w odpowiedź zapalną oraz procesy włóknienia $[4,5]$.

Białko ST-2 należy do nadrodziny receptorów Toll wiążących interleukinę 1 (TIR, Toll/interleukin-1 receptor) [7]. Ma dwie istotne klinicznie postacie: przezbłonową i rozpuszczalną. Forma przezbłonowa (ST-2L, ST-2 ligand) występuje przede wszystkim na komórkach zapalnych, kardiomiocytach i śródbłonku. W badaniach na zwierzętach wykazano, że interleukina 33 (IL-33), oddziałując z ST-2L obecnymi na kardiomiocytach, przeciwdziała przerostowi i włóknieniu miokardium [7]. Natomiast forma rozpuszczalna (SST-2, soluble ST-2) krąży swobodnie we krwi i możliwe jest dokonanie pomiaru jej stężenia w standardowym badaniu biochemicznym krwi $[7,8]$. Uwalnianie sST-2 jest regulowane przez stymulowane do wzrostu fibroblasty oraz przez cytokiny o charakterze prozapalnym - między innymi czynnik martwicy nowotworu $\alpha$ (TNF- $\alpha$, tumor necrosis factor $\alpha$ ) i IL-6 [8]. Nadmierne stężenie sST-2 zapobiega wiązaniu IL-33 z białkiem ST-2L, przyczyniając się do zachodzenia niekorzystnych zmian w strukturze serca [8]. Postuluje się również, że interakcja IL-33/ST-2, oprócz udziału we włóknieniu oraz przebudowie miokardium, bierze udział w progresji miażdżycy [8] (ryc. 2).

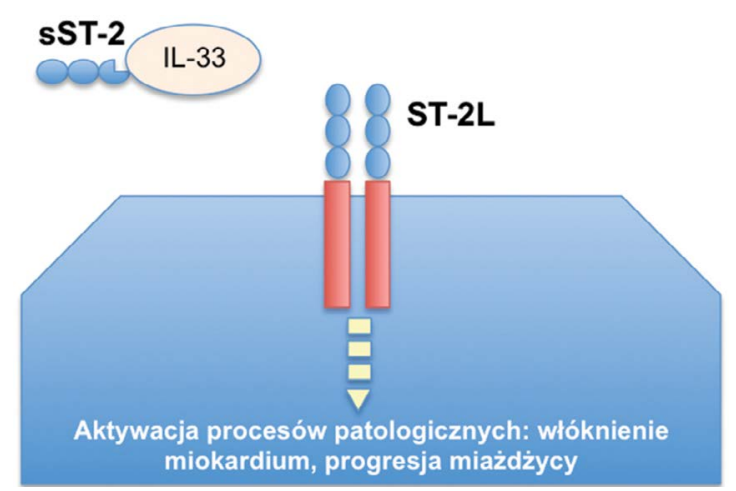

Rycina 2. Struktura formy przezbłonowej (ST-2L, suppression of tumorigenicity 2 ligand) oraz rozpuszczalnej (sST-2, soluble ST-2) białka ST-2 oraz mechanizm działania. Podwyższone stężenie sST-2 zapobiega wiązaniu interleukiny 33 (IL-33) z białkiem ST-2L, przyczyniając się do niekorzystnych zmian w strukturze serca

\section{Nowe perspektywy wykorzystania biomarkerów w praktyce klinicznej}

\section{Choroba wieńcowa}

W patogenezie miażdżycy podkreśla się przede wszystkim rolę procesu zapalnego. Obecnie poszukuje się czułych biomarkerów procesu zapalnego, które mogłyby pomóc we wczesnej i w skutecznej identyfikacji pacjentów o podwyższonym ryzyku wystąpienia choroby wieńcowej, a także w przewidywaniu odpowiedzi na leczenie i w ocenie rokowania.

Zawał serca prowadzi do martwicy mięśnia sercowego oraz zmian strukturalnych i biochemicznych w obrębie uszkodzonych tkanek. Zmiany te obejmują: odkładanie kolagenu z tworzeniem blizny, włóknienie, przerost oraz zmianę objętości jam serca, co określa się mianem remodelingu, który prowadzi do rozwoju niewydolności serca. Warto podkreślić, że pozawałowej przebudowie podlegaja również tkanki niepoddane niedokrwieniu, ma to na celu zachowanie skurczowej i rozkurczowej funkcji serca [9].

Zgodnie z ogólnopolską bazą ostrych zespołów wieńcowych AMI-PL (Nationwide Acute Myocardial Infarction Database in Poland) blisko 80\% pacjentów przyjętych z powodu zawału serca z uniesieniem odcinka ST (STEMI, ST-elevation myocardial infarction) jest poddawanych rewaskularyzacji wieńcowej [10]. Poprawa leczenia ostrych zespołów wieńcowych za pomocą przezskórnej angioplastyki wieńcowej (PCl, percutaneous coronary intervention) redukuje śmiertelność wewnątrzszpitalną, natomiast pozostawia liczną grupę pacjentów z uszkodzoną lewą komorą serca [3]. W bazie AMI-PL u pacjentów po zawale serca niewydolność serca stanowiła jedną z najczęstszych przyczyn powtórnych hospitalizacji [10]. 


\section{Rola Gal-3 w chorobie wieńcowej}

Stężenie Gal-3 jest istotnie wyższe u pacjentów z chorobą wieńcową, w której substrat zapalny jest jedną z głównych przyczyn aktywacji makrofagów [11]. Ponadto Gal-3 może wpływać na rozwój blaszek miażdżycowych przez uniemożliwienie skutecznego usuwania lipoprotein o niskiej gęstości (LDL, low-density lipoprotien) [12]. Wiadomo, że ekspresja Gal-3 jest wyraźnie zaznaczona w niestabilnych blaszkach miażdżycowych [11]. Rola Gal-3 w rozwoju miażdżycy jest poparta zarówno wynikami badań in vivo, jak i in vitro. Mackinnon i wsp. [13] wykazali, że farmakologiczne blokowanie Gal-3 w modelu mysim istotnie hamowało rozwój blaszki miażdżycowej.

W badaniach eksperymentalnych obserwowano wyższą ekspresję mRNA białka Gal-3 we wczesnym okresie po zawale serca, z maksimum osiąganym w ciągu pierwszego tygodnia, oraz stopniowym obniżaniem w kolejnych tygodniach. Stężenie Gal-3 wzrastało również w okolicznych tkankach nieobjętych bezpośrednio niedokrwieniem, natomiast maksymalna ekspresja została w nich osiągnięta już w pierwszej dobie [14]. Wydaje się, że wzrost stężenia Gal-3 we wczesnej fazie po zawale serca przyczynia się do aktywacji funkcji naprawczych w strefie uszkodzenia w celu zachowania geometrii i funkcji serca [15]. Jednak w dłuższym czasie przewlekła aktywacja prowadzi do włóknienia tkanek i przyspieszonego niekorzystnego remodelingu serca [15].

W badaniu prowadzonym przez Tsai i wsp. [16] w grupie 196 pacjentów ze świeżym STEMI wykazano, że stężenie Gal-3 wzrasta w pierwszych godzinach po PCl i jest niezależnym czynnikiem rokowniczym zgonu i rozwoju niewydolności serca we wczesnym (30-dniowym) okresie pozawałowym, niezależnie od zaawansowania zmian w tętnicach wieńcowych, frakcji wyrzutowej lewej komory (LVEF, left ventricular ejection fraction) oraz stężenia kreatyniny w surowicy. Należy jednak zaznaczyć, że Gal-3 jest ważnym biomarkerem włóknienia, a jej ekspresja rośnie również w przebiegu marskości wątroby czy postępującym włóknieniu nerek. Pogorszenie funkcji nerek w przebiegu niewydolności serca może znacząco wpływać na stężenie Gal-3, co z kolei może mieć odzwierciedlenie w jej wartości prognostycznej [17].

W badaniu Szadkowskiej i wsp. [18] pacjenci po zawale serca z podwyższonym stężeniem Gal-3 w okresie hospitalizacji charakteryzowali się wyższym ryzykiem rozwinięcia niewydolności serca i migotania przedsionków (AF, atrial fibrillation) de novo. Autorzy nie zaobserwowali natomiast korelacji między stężeniem Gal-3 a LVEF po zawale serca, podczas gdy taką korelację udokumentowano w odniesieniu do stężenia N-końcowego propeptydu natriuretycznego typu B (NT-proBNP, N-terminal pro-B-type natriuretic peptide) i białka C-reaktywnego oznaczanego metodą wysokoczułą (hsCRP, high-sensitivity C-reactive protein) [18].
W badaniu prowadzonym przez Weir i wsp. [19] w grupie 100 pacjentów po STEMI u każdego pacjenta wykonano pomiar stężenia Gal-3 oraz rezonans magnetyczny (MRI, magnetic resonance imaging) serca na początku badania oraz po 4 miesiącach. Nie wykazano zależności między stężeniem Gal-3 a LVEF i objętościami lewej komory ocenianymi w MRI wyjściowo, natomiast odnotowano odwrotną korelację między Gal-3 i LVEF po 4 miesiącach obserwacji. Ponadto przez całe badanie obserwowano korelację między stężeniem Gal-3 a NT-proBNP oraz białkami macierzy zewnątrzkomórkowej, takimi jak metaloproteinaza macierzy 3 (MMP-3, matrix metalloproteinase 3), tkankowy inhibitor metaloproteinazy macierzy 1 (TIMP-1, tissue inhibitor of matrix metalloproteinases 1), białko chemotaktyczne monocytów 1 (MCP-1, monocyte chemoattractant protein 1) i interleukiny 8 (IL-8, interleukin 8) [19]. W tej samej grupie obserwowano związek między wyższym stężeniem Gal-3 a bardziej intensywną przebudową serca u pacjentów z zachowaną LVEF (określaną w badaniu jako LVEF > 49,2\%) we wczesnym okresie po zawale serca, nie odnotowano tej zależności u osób z cięższą dysfunkcją lewej komory [19]. W badaniu prowadzonym przez van der Velde i wsp. [20] stężenie Gal-3, oznaczone bezpośrednio po zawale serca, przewidywało wartość LVEF i wielkość blizny pozawałowej po 4 miesiącach.

Podsumowując, istnieje związek między stężeniem Gal-3 a zwiększonym ryzykiem rozwoju niewydolności serca po zawale serca. Jednak z powodu niewielkich grup uczestniczących w badaniach oraz krótkiego czasu obserwacj wnioski z dotychczasowych badań wciąż są ograniczone.

\section{Rola białka ST-2 w chorobie wieńcowej}

Rola białka ST-2 była również badana w chorobie niedokrwiennej serca. Uważa się, że za pomocą oznaczeń białka ST-2 jest możliwe przewidywanie rokowania sercowo-naczyniowego, między innymi ryzyka zgonu u pacjentów z chorobą wieńcową, mimo że jego zastosowanie diagnostyczne jest ograniczone.

Seki i wsp. [21] wykazali, że IL-33, wiążąc się z przezbłonową formą ST-2, powoduje aktywację jądrowego czynnika transkrypcyjnego $k \mathrm{~B}$ (NF-kB, nuclear factor $k B)$, dzięki któremu może regulować przeżycie komórek. W badaniu na szczurach podskórne wstrzyknięcie IL-33 spowodowało zahamowanie apoptozy indukowanej przez niedokrwienie przez wzrost ekspresji białek odpowiedzialnych za inhibicje apoptozy oraz zmniejszenie aktywacji kaspazy 3, enzymu wzmagającego proces apoptozy. Doprowadziło to do zmniejszenia objętości mięśnia sercowego objętego zawałem oraz procesu włóknienia [21].

Ponadto uważa się, że szlak IL-33/białka ST-2 wiąże się z patogenezą miażdżycy. Wskazuje się, że czynny stan zapalny jest przyczyną niestabilności niektórych zmian miażdżycowych - prowadzi do pęknięcia blaszki oraz 


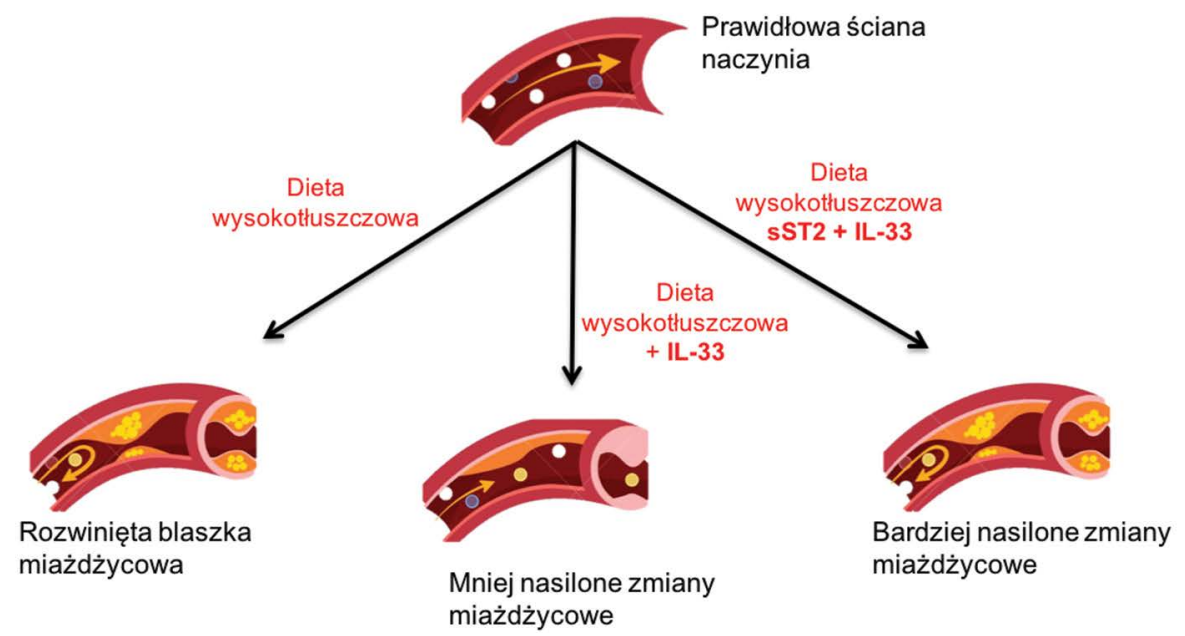

Rycina 3. Zmniejszanie progresji miażdżycy przez system interleukina 33 (IL-33)-białko ST-2 (suppression of tumorigenicity 2) (na podstawie [7])

następowego tworzenia się skrzeplin, doprowadzając do zamknięcia naczynia i zawału serca. Jedną ze strategii hamowania procesu zapalnego w naczyniach w przebiegu miażdżycy może być zwiększony udział komórek immunologicznych Th2. System IL-33/ST-2 może być jedną z dróg prowadzących do ich aktywacji. Myszy pozbawione genu apolipoproteiny $\mathrm{E}$, karmione dietą wysokotłuszczową, mają wysokie stężenie cholesterolu w surowicy i rozwija się u nich miażdżyca. Myszy, u których podano IL-33, wykazywały zmniejszoną liczbę blaszek miażdżycowych i niższe stężenia przeciwciał w surowicy względem utlenionego LDL w porównaniu z myszami kontrolnymi. Natomiast po wstępnej podaży rozpuszczalnej formy ST-2, jeszcze przed ekspozycją na IL-33, myszy te wykazywały zwiększoną miażdżycę tętnic w porównaniu z tymi nieleczonymi sST-2 (efekt anty-IL-33 rozpuszczalnej izoformy ST-2) (ryc. 3) [7].

Interleukina 33 w wyniku zmniejszenia stężenia interferonu $y$, który pobudza makrofagi do produkcji metaloproteinaz macierzy (MMP, matrix metalloproteinases), zapobiega destrukcji macierzy zewnątrzkomórkowej i destabilizacji blaszki miażdżycowej [22]. Stężenie MMP jest szczególnie wysokie w ostrej fazie zawału serca [22]. Guzel i wsp. [23] stwierdzili, że stężenie IL-33 w surowicy jest istotnie niższe u chorych z zawałem serca bez uniesienia odcinka ST (NSTEMI, non-ST-elevation myocardial infarction) niż w grupie kontrolnej i koreluje ujemnie ze stężeniem MMP9. Wzrost sST-2 i równoległe obniżenie stężenia IL-33 [23] podczas zawału serca mogą świadczyć o zwiększonym stopniu uszkodzenia mięśnia sercowego.

W wielu badaniach wykazano, że rozpuszczalna forma ST-2 jest ważnym biomarkerem po zawale serca [21, 24, 25]. Stężenie sST-2 wzrasta po kilku godzinach od zawału serca. Zaobserwowano, że przeciwdziałanie ochronnym właściwościom IL-33 zależy od stężenia SST-2 [21]. Co więcej, Richards i wsp. [24] stwierdzili, że najlepszą wartość rokowniczą ma wczesna ocena stężenia sST-2. Shimpo i wsp. [25] udowodnili wartość predykcyjną SST-2 u pacjentów po świeżym zawale serca z STEMI. Pacjenci z wyższym stężeniem sST-2 w surowicy mieli istotnie większe ryzyko zgonu lub wystąpienia nowo rozpoznanej niewydolności serca w ciągu 30 dni [25], choć ta zależność traciła istotność po uwzględnieniu peptydu natriuretycznego typu B (BNP, Btype natriuretic peptide) i troponiny sercowej I (cTnl, cardiac troponin I) w analizie wieloczynnikowej [25]. Jenkins i wsp. [26] na grupie 1400 pacjentów po zawale serca oceniali wartość predykcyjną w długoterminowej, 5-letniej, obserwacji. Podwyższone stężenia sST-2 występowały u połowy pacjentów z zawałem serca, a wyższe stężenia wiązały się z wysokim ryzykiem zgonu i rozwinięcia niewydolności serca niezależnie od innych predyktorów, takich jak wiek, płeć, choroby współtowarzyszące, troponina T czy klasa Killipa [26]. Świadczy to o konieczności dalszych badań nad oceną przydatności ST-2 w predykcji ryzyka rozwoju niewydolności serca po zawale serca.

Co interesujące, w badaniu CLARITY-TIMI 28 (CLopidogrel as Adjunctive Reperfuslon TherapY-Thrombolysis in Myocardial Infarction 28), obejmującym pacjentów po STEMI, udowodniono, że białko ST-2 jest niezależnym czynnikiem rokowniczym, a dodanie go do skali TIMI Risk Score poprawia ocenę rokowniczą chorych po STEMI. Sabatine i wsp. [27] wykazali, że połączenie białka ST-2 z NT-proBNP znacznie poprawia stratyfikację ryzyka w chorobie wieńcowej. Przeciwnie, poprawy stratyfikacji ryzyka nie stwierdzono po dołączeniu białka ST-2 do skali GRACE (Global Registry of Acute Coronary Events) u osób po NSTEMI [28].

Weir i wsp. [29] zaobserwowali, że u pacjentów po świeżym zawale serca stężenia sST-2 były dodatnio skorelowane z rozległością zawału serca oraz przewidywały niekorzystną 
przebudowę lewej komory ocenianą za pomocą MRI w ciągu 24-tygodniowej obserwacji. Zmiana stężenia sST-2 (oceniana wyjściowo oraz po 24 tygodniach) wiązała się z istotną zmianą objętości końcoworozkurczowej lewej komory [29]. Nie wykazano, aby sST-2 pozwalało przewidzieć wystąpienie ponownego zawału serca [24].

\section{Rola biomarkerów w innych sytuacjach klinicznych}

Udowodniono, że wyższe stężenia Gal-3 wiążą się z większym ryzykiem rozwoju AF w 10-letniej obserwacji, niezależnie od wieku i płci [30]. Zależność ta natomiast nie była obserwowana po uwzględnieniu innych typowych czynników ryzyka rozwoju AF [30]. Podwyższone stężenie Gal-3 również wykazano u pacjentów z przetrwałym AF bez współistniejącej choroby strukturalnej serca [31]. Wciąż jednak nie wiadomo, czy ocena Gal-3 może być pomocna w identyfikacji tych pacjentów z AF, u których zabieg izolacji żył płucnych przyniósłby największe korzyści [31, 32]. Kontrowersyjne dane dotyczą również oceny ryzyka nawrotu arytmii po ablacji [31, 32]. Chen i wsp. [33] badali stężenia sST-2 u pacjentów z AF niezwiązanym ze stenozą mitralną lub protezą zastawkową oraz u pacjentów z rytmem zatokowym. Zaobserwowali wyższe stężenia sST-2 u pacjentów z AF oraz dodatnią korelację z wymiarem lewego przedsionka. Nie stwierdzono różnic między pacjentami z napadowym i przetrwałym AF. Podczas 6-miesięcznej obserwacji badacze wykazali, że sST-2 oraz wymiar lewego przedsionka są niezależnymi czynnikami rozwoju niewydolności serca u pacjentów z tak zwanym niezastawkowym AF [33].

Na podstawie licznych badań dowiedziono znaczenie białka ST-2 i Gal-3 w przewlekłej i ostrej niewydolności serca. Znalazło to swoje odzwierciedlenie w wytycznych Amerykańskiego Towarzystwa Kardiologicznego (AHA, American Heart Association), w których uznano białko ST-2 oraz Gal-3 jako wartościowe dodatkowe markery diagnostyczne i rokownicze w ostrej i przewlekłej niewydolności serca (klasa zaleceń Ilb, poziom dowodu B) [34]. Wykazano, że siła predykcyjna obu biomarkerów rośnie w połączeniu z NT-proBNP, a strategie terapii niewydolności serca oparte na pomiarach kilku biomarkerów mogą przynieść dodatkowe korzyści.

W wieloośrodkowym badaniu populacyjnym Framingham Heart Study stężenie sST-2 wzrastało z wiekiem oraz wiązało się z wyższym ciśnieniem tętniczym, częstszym stosowaniem leków hipotensyjnych oraz częstszym współistnieniem cukrzycy [35]. Zaobserwowano również wyższe stężenia białka ST-2 u pacjentów ze stenozą aortalną [36]. Naturalny przebieg tej wady serca prowadzi do przeciążenia lewej komory serca i jej przerostu, a w dalszej kolejności - do włóknienia i remodelingu mięśnia sercowego. Stundl i wsp. [37] oceniali związek stężeń sST-2 mierzonych przed zabiegiem przezcewnikowej implantacji zastawki aortalnej (TAVI, transcatheter aortic valve implantation) z rokowaniem. Wykazano, że wyjściowe stężenie sST-2 powyżej $29 \mathrm{ng} / \mathrm{ml}$ wiąże się z niekorzystnym rokowaniem po zabiegu TAVI i może być przydatne w przewidywaniu krótko- i długoterminowej śmiertelności. Jednak białko sST-2 nie wykazywało przewagi nad NT-proBNP ani stosowanymi obecnie chirurgicznymi algorytmami oceny ryzyka (EuroSCORE II [European System for Cardiac Operative Risk Evaluation], STS PROM [Society of Thoracic Surgeons Predicted Risk of Mortality]) [37].

Wojciechowska i wsp. [38] wykazali, że białko ST-2 może być przydatne w ocenie rokowania u pacjentów z kardiomiopatią rozstrzeniową. Ponadto w modelu hypertroficznego mięśnia sercowego lub podczas aktywnego zapalenia miokardium występuje znaczna infiltracja aktywowanych makrofagów ze zwiększeniem stężeń Gal-3 [39]. W subanalizie wieloośrodkowego badania MADIT-CRT (Multicenter Automatic Implantation Trial With Resynchronization Therapy) oceniano korzyść z zastosowania terapii resynchronizującej serce (CRT, cardiac resynchronization therapy) u pacjentów z objawami niewydolności serca o niewielkim nasileniu (I-II w skali New York Heart Association [NYHA]) w zależności od stężenia Gal-3. Dowiedziono, że chorzy z wyższymi stężeniami Gal-3 bardziej korzystali z tej terapii [40]. Autorzy sugerują, że podwyższone stężenie Gal-3 w tej podgrupie pacjentów z niewydolnością serca świadczy o toczących się procesach włóknienia, co powoduje, że mogą oni lepiej odpowiadać na terapię CRT i jej właściwości przeciwdziałające włóknieniu oraz procesowi remodelingu mięśnia sercowego [40].

\section{Nowe perspektywy terapeutyczne}

Zakładając, że Gal-3 i białko ST-2 wiążą się z ryzykiem rozwinięcia pozawałowej niewydolności serca, można wysunąć hipotezę, że stosowanie leków, które mają zmniejszać niepożądany remodeling serca, takich jak inhibitory konwertazy angiotensyny, sartany lub antagonistów receptora aldosteronowego, może być szczególnie korzystne u pacjentów ze zwiększonym stężeniem tych markerów po zawale. Co ważne, wykazano, że przeciwdziałanie niekorzystnej przebudowie mięśnia sercowego przez eplerenon jest silniejsze u pacjentów z wysokim stężeniem sST-2 [41]. Ponadto istnieją doniesienia, że możliwe jest zahamowanie progresji niewydolności serca przez blokowanie farmakologiczne lub genetyczne biomarkerów, co daje dodatkową perspektywę wykorzystania szlaków metabolizmu tych białek w terapii niewydolności serca [7, 42]. Dostępne są również dane świadczące o lepszej odpowiedzi na leczenie statynami u pacjentów z niższym stężeniem Gal-3 [17]. 


\section{Podsumowanie}

Potrzeba rozszerzenia algorytmów diagnostycznych przyczyniła się do przeprowadzenia wielu badań nad nowymi markerami. Liczne badania i publikacje wskazują na możliwość wszechstronnego wykorzystania Gal-3 i białka ST-2. Wykazano między innymi, że Gal-3 oraz białko ST-2 dzięki swojemu związkowi z procesami włóknienia mogą się okazać kluczowymi markerami u pacjentów z chorobą wieńcową oraz po zawale serca. Sugeruje się, że Gal-3 w początkowych etapach po zawale serca przyczynia się do prawidłowej naprawy tkanek, jednak z czasem jej nadmierna aktywacja prowadzi do niekorzystnego remodelingu lewej komory. Białko ST-2 może dostarczyć cennych informacji prognostycznych dotyczących ryzyka rozwoju niewydolności serca. Dodatkowo istnieją doniesienia o wykorzystaniu nowych biomarkerów do oceny rokowania po zabiegu TAVI czy przewidywania korzyści płynących z terapii resynchronizującej serce. Trwają badania nad farmakologicznymi lub genetycznymi możliwościami ingerowania w szlaki obydwu cząsteczek. Jednak ze względu na niewielkie grupy badanych pacjentów oraz stosunkowo krótki czas obserwacji wnioski płynące z tych badań są ograniczone.

\section{Konflikt interesów}

Autorzy deklarują brak konfliktu interesów.

\section{Abstract}

There are many markers for the risk assessment of cardiovascular diseases. New sensitive and specific biomarkers that could help stratify risk, in both healthy and cardiovascular populations, are still being sought. Galectin 3 and ST-2 seem to be very promising molecules. However, further research is needed to establish their full diagnostic and prognostic value. We present a review of the literature showing the possibility of comprehensive use of both biomarkers, especially in coronary artery disease. Galectin 3 and ST-2, through their association with fibrotic processes, may prove to be beneficial in patients with coronary disease and following myocardial infarction.

Key words: cardiovascular diseases, coronary artery disease, galectin 3, myocardial infarction, remodelling, ST-2

Folia Cardiologica 2019; 14, 1: 52-59

\section{Piśmiennictwo}

1. Gierczyński J, Gryglewicz J, Karczewicz E, Zalewska H. Niewydolność serca - analiza kosztów ekonomicznych i społecznych. Uczelnia Łazarskiego, Warszawa 2013.

2. Ciccone MM, Scicchitano P, Zito A, et al. Correlation between coronary artery disease severity, left ventricular mass index and carotid intima media thickness, assessed by radio-frequency. Cardiovasc Ultrasound. 2011; 9: 32, doi: 10.1186/1476-7120-9-32, indexed in Pubmed: 22087814.

3. Ibanez B, James S, Agewall S, et al. ESC Scientific Document Group. 2017 ESC Guidelines for the management of acute myocardial infarction in patients presenting with ST-segment elevation: The Task Force for the management of acute myocardial infarction in patients presenting with ST-segment elevation of the European Society of Cardiology (ESC). Eur Heart J. 2018; 39(2): 119-177, doi: 10.1093/ /eurheartj/ehx393, indexed in Pubmed: 28886621.

4. Yang RiY, Rabinovich GA, Liu FT. Galectins: structure, function and therapeutic potential. Expert Rev Mol Med. 2008; 10: e17, doi: 10.1017/ /S1462399408000719, indexed in Pubmed: 18549522.

5. Ho JE, Liu C, Lyass A, et al. Galectin-3, a marker of cardiac fibrosis, predicts incident heart failure in the community. J Am Coll Cardiol. 2012; 60(14): 1249-1256, doi: 10.1016/j.jacc.2012.04.053, indexed in Pubmed: 22939561.

6. Barboni EA, Bawumia S, Henrick K, et al. Molecular modeling and mutagenesis studies of the $\mathrm{N}$-terminal domains of galectin-3: evidence for participation with the C-terminal carbohydrate recognition domain in oligosaccharide binding. Glycobiology. 2000; 10(11): 1201-1208, indexed in Pubmed: 11087712.

7. Kakkar R, Lee RT. The IL-33/ST2 pathway: therapeutic target and novel biomarker. Nat Rev Drug Discov. 2008; 7(10): 827-840, doi: 10.1038/nrd2660, indexed in Pubmed: 18827826.

8. Shimpo M, Morrow DA, Weinberg EO, et al. Expression and regulation of ST2, an interleukin-1 receptor family member, in cardiomyocytes and myocardial infarction. Circulation. 2002; 106(23): 2961-2966, indexed in Pubmed: 12460879.

9. Meijers WC, van der Velde AR, Pascual-Figal DA, et al. Galectin-3 and post-myocardial infarction cardiac remodeling. Eur J Pharmacol. 2015; 763(Pt A): 115-121, doi: 10.1016/j.ejphar.2015.06.025, indexed in Pubmed: 26101067.

10. Gierlotka M, Zdrojewski T, Wojtyniak B, et al. Incidence, treatment, in-hospital mortality and one-year outcomes of acute myocardial infarction in Poland in 2009-2012--nationwide AMI-PL database. Kardiol Pol. 2015; 73(3): 142-158, doi: 10.5603/KP.a2014.0213, indexed in Pubmed: 25371307.

11. Papaspyridonos M, McNeill E, de Bono JP, et al. Galectin-3 is an amplifier of inflammation in atherosclerotic plaque progression through macrophage activation and monocyte chemoattraction. Arterioscler Thromb Vasc Biol. 2008; 28(3): 433-440, doi: 10.1161/ATVBAHA.107.159160, indexed in Pubmed: 18096829. 
12. Iacobini C, Menini S, Ricci C, et al. Advanced lipoxidation end-products mediate lipid-induced glomerular injury: role of receptor-mediated mechanisms. J Pathol. 2009; 218(3): 360-369, doi: 10.1002/path.2536, indexed in Pubmed: 19334049.

13. Mackinnon AC, Liu X, Hadoke PWf, et al. Inhibition of galectin-3 reduces atherosclerosis in apolipoprotein E-deficient mice. Glycobiology. 2013; 23(6): 654-663, doi: 10.1093/glycob/cwt006, indexed in Pubmed: 23426722.

14. Sanchez-Mas J, Lax A, Asensio-Lopez MC, et al. Galectin-3 expression in cardiac remodeling after myocardial infarction. Int J Cardiol. 2014; 172(1): e98-e9e101, doi: 10.1016/j.ijcard.2013.12.129, indexed in Pubmed: 24433619.

15. González GE, Cassaglia P, Noli Truant S, et al. Galectin-3 is essential for early wound healing and ventricular remodeling after myocardial infarction in mice. Int J Cardiol. 2014; 176(3): 1423-1425, doi: 10.1016/j.ijcard.2014.08.011, indexed in Pubmed: 25150483.

16. Tsai TH, Sung PH, Chang LT, et al. Value and level of galectin-3 in acute myocardial infarction patients undergoing primary percutaneous coronary intervention. J Atheroscler Thromb. 2012; 19(12): 1073-1082, indexed in Pubmed: 23037954.

17. Gullestad L, Ueland T, Kjekshus J, et al. CORONA Study Group. Galectin-3 predicts response to statin therapy in the Controlled Rosuvastatin Multinational Trial in Heart Failure (CORONA). Eur Heart J. 2012; 33(18): 2290-2296, doi: 10.1093/eurheartj/ehs077, indexed in Pubmed: 22513778.

18. Szadkowska I, Wlazeł RN, Migała M, et al. The association between galectin-3 and clinical parameters in patients with first acute myocardial infarction treated with primary percutaneous coronary angioplasty. Cardiol J. 2013; 20(6): 577-582, doi: 10.5603/CJ.2013.0157, indexed in Pubmed: 24338533.

19. Weir RAP, Petrie C, Murphy $C$, et al. Galectin-3 and cardiac function in survivors of acute myocardial infarction. Circ Heart Fail. 2013; 6(3): 492-498, doi: 10.1161/circheartfailure.112.000146.

20. van der Velde AR, Lexis CPH, Meijers WC, et al. Galectin-3 and SST2 in prediction of left ventricular ejection fraction after myocardial infarction. Clin Chim Acta. 2016; 452: 50-57, doi: 10.1016/j. cca.2015.10.034, indexed in Pubmed: 26528636.

21. Seki K, Sanada S, Kudinova AY, et al. Interleukin-33 prevents apoptosis and improves survival after experimental myocardial infarction through ST2 signaling. Circ Heart Fail. 2009; 2(6): 684-691, doi: 10.1161/CIRCHEARTFAILURE.109.873240, indexed in Pubmed: 19919994.

22. Dominguez-Rodriguez A, Abreu-Gonzalez P. Clinical implications of elevated serum interleukin-6, soluble CD40 ligand, metalloproteinase- 9 , and tissue inhibitor of metalloproteinase- 1 in patients with acute ST-segment elevation myocardial infarction. Clin Cardiol. 2009; 32(5): 288, doi: 10.1002/clc.20464, indexed in Pubmed: 19452490.

23. Guzel S, Serin 0, Guzel EC, et al. Interleukin-33, matrix metalloproteinase-9, and tissue inhibitor [corrected] of matrix metalloproteinase-1 in myocardial infarction. Korean J Intern Med. 2013; 28(2): 165-173, doi: 10.3904/kjim.2013.28.2.165, indexed in Pubmed: 23525523.

24. Richards AM, Di Somma S, Mueller T. ST2 in stable and unstable ischemic heart diseases. Am J Cardiol. 2015; 115(7 Suppl): 48B-58B, doi: 10.1016/j.amjcard.2015.01.041, indexed in Pubmed: 25678392.

25. Shimpo M, Morrow DA, Weinberg EO, et al. Serum levels of the interleukin-1 receptor family member ST2 predict mortality and clinical outcome in acute myocardial infarction. Circulation. 2004; 109(18):
2186-2190, doi: 10.1161/01.CIR.0000127958.21003.5A, indexed in Pubmed: 15117853.

26. Jenkins WS, Roger VL, Jaffe AS, et al. Prognostic value of soluble ST2 after myocardial infarction: a community perspective. Am J Med. 2017; 130(9): 1112.e9-1112.e15, doi: 10.1016/j.amjmed.2017.02.034, indexed in Pubmed: 28344136.

27. Sabatine MS, Morrow DA, Higgins $\sqcup$, et al. Complementary roles for biomarkers of biomechanical strain ST2 and N-terminal prohormone B-type natriuretic peptide in patients with ST-elevation myocardial infarction. Circulation. 2008; 117(15): 1936-1944, doi: 10.1161/ CIRCULATIONAHA.107.728022, indexed in Pubmed: 18378613.

28. Dhillon OS, Narayan HK, Quinn PA, et al. Interleukin 33 and ST2 in non-ST-elevation myocardial infarction: comparison with Global Registry of Acute Coronary Events Risk Scoring and NT-proBNP. Am Heart J. 2011; 161(6): 1163-1170, doi: 10.1016/j.ahj.2011.03.025, indexed in Pubmed: 21641364.

29. Weir RAP, Miller AM, Murphy GEJ, et al. Serum soluble ST2: a potential novel mediator in left ventricular and infarct remodeling after acute myocardial infarction. J Am Coll Cardiol. 2010; 55(3): 243-250, doi: 10.1016/j.jacc.2009.08.047, indexed in Pubmed: 20117403.

30. Ho JE, Yin X, Levy D, et al. Galectin 3 and incident atrial fibrillation in the community. Am Heart J. 2014; 167(5): 729-734.e1, doi: 10.1016/j.ahj.2014.02.009, indexed in Pubmed: 24766984.

31. Wu XY, Li SN, Wen SN, et al. Plasma galectin-3 predicts clinical outcomes after catheter ablation in persistent atrial fibrillation patients without structural heart disease. Europace. 2015; 17(10): 1541-1547, doi: 10.1093/europace/euv045, indexed in Pubmed: 25921557.

32. Kornej J, Schmidl J, Ueberham L, et al. Galectin-3 in patients with atrial fibrillation undergoing radiofrequency catheter ablation. PLoS One. 2015; 10(4): e0123574, doi: 10.1371/journal.pone.0123574, indexed in Pubmed: 25875595.

33. Chen C, Qu X, Gao Z, et al. Soluble ST2 in patients with nonvalvular atrial fibrillation and prediction of heart failure. Int Heart J. 2018; 59(1): 58-63, doi: 10.1536/ihj.16-520, indexed in Pubmed: 29279523.

34. Yancy CW, Jessup M, Bozkurt B, et al. 2013 ACCF/AHA guideline for the management of heart failure: executive summary: a report of the American College of Cardiology Foundation/American Heart Association Task Force on practice guidelines. Circulation. 2013; 128(16): 1810-1852, doi: 10.1161/CIR.0b013e31829e8807, indexed in Pubmed: 23741057.

35. Coglianese EE, Larson MG, Vasan RS, et al. Distribution and clinical correlates of the interleukin receptor family member soluble ST2 in the Framingham Heart Study. Clin Chem. 2012; 58(12): 1673-1681, doi: 10.1373/clinchem.2012.192153, indexed in Pubmed: 23065477.

36. Lancellotti P, Dulgheru R, Magne J, et al. Elevated plasma soluble ST2 is associated with heart failure symptoms and outcome in aortic stenosis. PLoS One. 2015; 10(9): e0138940, doi: 10.1371/journal. pone.0138940, indexed in Pubmed: 26390433.

37. Stundl A, Lünstedt NS, Courtz F, et al. Soluble ST2 for risk stratification and the prediction of mortality in patients undergoing transcatheter aortic valve implantation. Am J Cardiol. 2017; 120(6): 986-993, doi: 10.1016/j.amjcard.2017.06.033, indexed in Pubmed: 28739033.

38. Wojciechowska C, Romuk E, Nowalany-Kozielska E, et al. Serum galectin-3 and ST2 as predictors of unfavorable outcome in stable dilated cardiomyopathy patients. Hellenic J Cardiol. 2017; 58(5): 350-359, doi: 10.1016/j.hjc.2017.03.006, indexed in Pubmed: 28363768. 
39. Sharma UC, Pokharel S, van Brakel TJ, et al. Galectin-3 marks activated macrophages in failure-prone hypertrophied hearts and contributes to cardiac dysfunction. Circulation. 2004; 110(19): 31213128, doi: 10.1161/01.CIR.0000147181.65298.4D, indexed in Pubmed: 15520318.

40. Stolen CM, Adourian A, Meyer TE, et al. Plasma galectin-3 and heart failure outcomes in MADIT-CRT (multicenter automatic defibrillator implantation trial with cardiac resynchronization therapy). J Card Fail. 2014; 20(11): 793-799, doi: 10.1016/j.cardfail.2014.07.018, indexed in Pubmed: 25106783.
41. Weir RAP, Miller AM, Murphy GEJ, et al. Serum soluble ST2: a potential novel mediator in left ventricular and infarct remodeling after acute myocardial infarction. J Am Coll Cardiol. 2010; 55(3): 243-250, doi: 10.1016/j.jacc.2009.08.047, indexed in Pubmed: 20117403.

42. Yu L, Ruifrok WPT, Meissner M, et al. Genetic and pharmacological inhibition of galectin-3 prevents cardiac remodeling by interfering with myocardial fibrogenesis. Circ Heart Fail. 2013; 6(1): 107-117, doi: 10.1161/CIRCHEARTFAILURE.112.971168, indexed in Pubmed: 23230309. 